\section{Gritty philosophical thinking about food justice doing}

\author{
Review by Christine M. Porter* \\ University of Wyoming
}

Review of Food justice in U S and global contex ts: Bringing theory and practioe together, edited by Ian Werkheiser and Zachary Piso. (2017). Published by Springer. Available as hardcover, paperback, and ebook; 312 pages.

Publisher's website:

https:/ / www.springer.com/ us/ book/ 9783319571737
The International tibrary of Environmental,

Agricultural and Food Ethics 24

Ian Werkheiser

Zachary Piso Editors

\section{Food Justice} in US and Global Contexts

Submitted May 21, 2018 / Published online November 6, 2018

Citation: Porter, C. M. (2018). Gritty philosophical thinking about food justice doing [Book review]. Journal of A griculture, F ood Systems, and C ommunity D evelopment, 8(3), 221-224. https:/ / doi.org/ 10.5304/ jafscd.2018.083.009

Copyright ( 2018 by the Author. Published by the Lyson Center for Civic Agriculture and Food Systems. Open access under CC BY license.

W hat do academics who work in the humanities and social sciences have to offer to food justice, if anything? An academic colleague and friend in civic studies once posed this question to me. The 33 editors and contributing authors who produced this book aim to offer concrete examples of potential answers to this question.

However, none of these authors, my civic

* Christine M. Porter is associate professor and Wyoming Excellence Chair of Community and Public Health, Division of Kinesiology \& Health, College of Health Sciences, at the University of Wyoming; 1000 East University Avenue, D epartment 3196; Laramie, WY 82071 USA. She can be reached at christine.porter@uwyo.edu. studies colleague, nor I are in a good position to lead Sustainable Agricultural Systems proposals for USD A's Agricultural and Food Research Initiative (USD A AFRI). This new program area, announced in April 2018, will fund US\$10-million, five-year projects that aim, for example, to increase use efficiency of three crop inputs (water, nitrogen and phosphorus) by $50 \%$, reduce crop losses by $20 \%$, or reduce food-borne illnesses to 8.5 cases per 100,000 Americans each year. ${ }^{1}$

These technical goals have clear and practical food production applications. The first two also attend to the right of future generations to have enough to eat. However, today they do little or

1 https:/ / nifa.usda.gov/ sites/ default/ files/ rfa/ FY-2018-AFRI-SAS.pdf; https:// nifa.usda.gov/ resource/ afri-sas-faq\#ChallengeAreas 
nothing to promote food justice. Sufficient food supply is not a problem yet. However, inequitable distribution of the means of food production, exchange, and consumption are current problems; and within the U.S., this maldistribution closely, and unjustly, follows lines of class, gender, and race.

These food justice issues of distribution are moral and political problems, not scientific ones. In this volume, the editors proffer "signs of hope for the success of public philosophy" (p. xiii), providing guidance for U.S. society for navigating the wickedly problematic ethical and political terrains of food injustice and food system unsustainability.

The book grapples with food justice in four domains: global context, built environment, governance, and animal lives. Each of the associated sections opens with a brief vignette about a specific food justice practice or organization on the ground. These are authored or co-authored by people actually doing that work. Perhaps because the work of activists is generally doing the work rather than analyzing it in writing, these brief pieces tend toward descriptions rather than discussion. Also, though one goal of this volume is to offer "examples of what such engaged scholarship and theoretically informed practice can look like" (p. xiii), only the vignette in the Animal Lives section actively attaches itself to the chapters that follow. The scholarship in this book grapples deeply with real-life food and food justice practices, but, per my colleague's question above, how much practitioners value this array of scholarship as contributions to their work, in this volume and more generally, is less clear.

Each vignette is followed by an introductory "roadmap" to the section's three to four original scholarship chapters. Of these, Paul Thompson's introduction to governance is well worth reading and assigning as reading on its own. Heldke's summary of the Animal Lives section also provides a succinct "CliffsNotes" for the four chapters that follow.

Nearly every one of the research chapters offers substantially new and applied contributions to the food justice literature, and none has appeared in similar forms before in print. These authors are not taking advantage of a book format to sidestep rigor, but taking advantage, in the best sense of that word, to embrace new and innovative ways of applying philosophy and social sciences to food justice issues.

Discussing the merits of any individual chapters raises questions about whom they are engaging in conversation. In my case, I volunteered to review this book for two reasons. O ne, I'm deeply interested the role of academia in promoting food justice. Two, it meant I could get a copy of the book without paying US\$109 for an e-copy or US\$129 for a paper one (which is my tree-killing preference for substantive and sometimes dense reading like this book offers). The price point alone makes this book accessible mainly to academics-and generally, even then, as part of a library collection. (Because of the quality and diversity of this collection, I will say that every university library should have a copy.)

A few chapters might be of interest directly to food justice activists, if they can access them. Most animal rights activists and all animal ethics scholars would find the four Animal Lives chapters, along with the preceding vignette and introduction, to be provocative. This collection makes a range of ethical arguments in favor of eating animal flesh. Within that section, hunters who ponder the lives of those they hunt would enjoy McConnell's autoethnographic, phenomenological, and accessible examination of being predator and/ or prey. In addition, the G overnance section's chapter on food gleaning offers a cogent, rigorous, and insightful review of the history of gleaning in the U.S., as well as current practice and policy that would be useful for any organization doing, or thinking of doing, work in that arena (by Leasure-Earnhardt, Scrufari, and Valentine).

Overall, for the growing array of academics striving for transdisciplinary--or even postdisciplinary--work in food justice and food systems, the $\mathrm{G}$ overnance section in particular may make this book worth buying or borrowing. In addition to Thompson's introduction and the gleaning review, it contains an incisive geopolitical analysis of the notion of "security" and power in relation to food (by Brisman and South). It also contains a brilliant essay using the case of Anishinaabe-University of Minnesota relations in wild rice research to 
question whether academic commodification of knowledge blocks academic work from being systematically useful to (by being in solidarity with) food justice practice (by Bowman). Of all the chapters, this one most directly addresses questions of how academic work could, but mainly does not, promote food justice.

The editors, seeking lessons for the U.S. food justice movement, included two ethnographic case studies in the Global Context section: one of the Cuban permaculture movement (by Williams) and one of Brazil's landless workers movement, or MST, within one settlement in the state of Mato G rosso (by Chávez). The rigor of their methods, lucid reporting of findings, and insightfulness of the discussions would make both excellent upper undergraduate or graduate readings in food system and food justice courses.

The two chapters set in education settings serve, in my view, as extended vignettes. O ne shares stories by each of four schoolteachers tangling with food injustice and insecurity in their schools, each in their own way (by Stapleton, Cole, Washburn, Jason, and Alvarado). The other shares "community engaged, student-centered" (Johnson, p. 201) learning and teaching experiences in undergraduate and graduate food education.

A chapter by Noll examines ways in which physical and geopolitical histories of U.S. cities may be barriers to present-day urban agriculture and food sovereignty projects in a wide-ranging yet highly specific tracing of some policy roots. The most theoretical chapter might be a discussion of the meaning of individual and collective memories, heirloom seeds and foods, and culinary communities by Leichter, in which my favorite line is: "the loss of biodiversity is one form of forgetting" ( $p$. 17). An examination of cultural loss suffered by traditional whaling communities as a result of hunting moratoriums is, by contrast, a narrow and highly applied ethical analysis (by Mattes); this appears in the G lobal Context section, but would fit well in Animal Lives, with its pro-flesh-consumption perspective and punchline of "how global antiwhaling discourse may save whales, but harm human-whale relations in Japan" (Mattes, p. 67).

A critical discourse analysis of U.S. mobile produce market websites (by Mari) stood out for me for two reasons. O ne, again, was the rigor of the methods. The other was the finding that "most mobile market organizations do not operate from a food justice perspective, but instead, operate from a food availability perspective" (p. 148). As an American, I confess I have food movement envy of the MST and Via Campesina, and the seats they have secured for food sovereignty leadership at UN FAO tables in Rome (McMichael \& Porter, 2018). I do also worry about the nonradical discourses common in community food work in the U.S. (see, e.g., "the type of political action recommended by US organizations is certainly tame compared to that undertaken by some of their international counterpart- I could not find a single call to commit civil disobedience" [Fairbairn, 2012, p. 224]). However, in my own action and research partnerships in the U.S., my experience is that the neoliberal context in the U.S. forces people to choose between openly flying radical flags for justice and their organizations' survival. In other words, though some operations are genuinely neoliberal, I would say many are simply camouflaged for survival as they do their organizing work. Finally, if academics would like their work to support food justice practices, I'm not sure further analysis from ivory towers focusing solely on whether people sweating the work on the ground are reproducing or resisting neoliberalism is the most useful or ethical place to direct our efforts. We could perhaps more productively and (for those of us merely watching from the sidelines) ethically ask, for example, how neoliberalism constrains their work and document promising strategies for resisting it.

As in nearly all edited books, this is not a methodical survey of the most prominent issues in the field (academically and more literally), or even of the question of how to make theory serve food justice practice. It is a compilation of what people who produced it happen to care about, at least in association with the workshops convened at Michigan State University starting in 2013 on "Food Justice and Peace: Bringing theory and practice," where this work originated. It offers, overall, a collection of highly applied, deeply considered philosophical and anthropological analyses of work and practices for food justice. It 
succeeds as public philosophy by engaging food practices in theory. If the next volume offered a meta-analysis, guided by the thinking in Bowman's chapter about the relations between academic and activist work, then we might succeed in making theory better serve food justice practice.

\section{References}

Fairbairn, M. (2012). Framing transformation: The counter-hegemonic potential of food sovereignty in the US context. A griculture and H uman V alues, 29(2), 217-230. https:/ / doi.org/ 10.1007/ s10460-011-9334-X

McMichael, P., \& Porter, C. M. (2018). G oing public with notes on close cousins, food sovereignty, and dignity. Journal of A griculture, Food Systems, and Community D evelopment, 8(Suppl. 1), 207-212.

https:// doi.org/ 10.5304/ jafscd.2018.08A.015 